\title{
Application of plant natural products for the management of postharvest diseases in fruits
}

\author{
Chunpeng Wan ${ }^{1, *}$ İbrahim Kahramanoğlu², Volkan Okatan \\ ${ }^{1}$ Jiangxi Key Laboratory for Postharvest Technology and Nondestructive Testing of Fruits \& Vegetables / Collaborative \\ Innovation Center of Postharvest Key Technology and Quality Safety of Fruits and Vegetables in \\ Jiangxi Province, College of Agronomy, Jiangxi Agricultural University, Nanchang 330045, China \\ ${ }^{2}$ Department of Horticulture, Faculty of Agricultural Sciences and Technologies, European University of Lefke, \\ Gemikonagi, Northern Cyprus, via Mersin 10, Turkey \\ ${ }^{3}$ Department of Horticulture, Faculty of Agriculture, Eskişehir Osmangazi University, Eskişehir, Turkey
}

\begin{abstract}
Prevention of postharvest losses has been a very important concern in the scientific world for many centuries, since adoption of an effective means to curtail such losses is believed to help in reaching sustainability in horticultural production and prevention of hunger around the world. The main means of deterioration in fruits, which may occur after harvest, include physiological changes/losses, physical losses, biochemical changes, changes in enzymatic activities and pathological deterioration. Among these, diseases cover the most important part; the losses due to diseases range from $5 \%$ to $20 \%$, and this figure may extend up to $>50 \%$ in the cases of certain susceptible cultivars. Fungicides have been the most important tool for the management of postharvest diseases for many years, together with hygiene, cold storage and packaging. However, due to the scientifically confirmed hazards of agro-chemicals on environment and human health, the acceptability of agro-chemicals decreased and scientists turned their attention towards natural alternatives. Most tropical and subtropical fruits contain a superficial cuticle, which helps them to regulate respiration and transpiration and protects against microbial decay. However, the waxy cuticle is generally being removed or damaged during washing or other handling practices. Therefore, the application of protective coatings (including wax) has been used in the fruit industry since the twelfth century, against microbial decay and for maintaining an acceptable standard of postharvest quality. This review aims to summarise and discuss the main natural products used for this purpose, to provide a broad-in-scope guide to farmers and the fruit storage sector.
\end{abstract}

Keywords: edible coatings, lipid-based films, protein-based films, polysaccharide-based films, postharvest diseases

\section{INTRODUCTION}

The total amount of horticultural crops (including fruits, vegetables, treenuts, root and tubers) produced in 2019 was estimated to be approximately $3.05 \mathrm{M}$ tonnes, of which fruits comprised $>34 \%$ (FAO, 2021). Huge efforts and natural resources are being used for the production of these crops. Thus, each and every one of these products is very important both for ensuring sustainability in horticultural production and for human consumption. However, several studies have estimated that around $30-50 \%$ of horticultural products never reach the final consumers due to postharvest losses, which is highly dependent on products' physiology and can be lower or higher (Gunders, 2017; Kahramanoğlu, 2017). Prevention or lowering of these losses would result in a reduction in the need for horticultural production, which then reduces the pressure on the natural resources. This is crucial for ensuring sustainability in horticultural production, where the availability of natural resources have been decreasing while the human population is continuously increasing (Cole et al., 2018; Kang et al., 2009).

Freshly harvested fruits and vegetables are alive and they continue to undergo respiration and 
transpiration, which are the main causes of senescence and deterioration of the fruits (Kahramanoğlu, 2017). The main means of deterioration in fruits include physiological changes/losses (ageing, colour changes, chilling injury, freezing injury etc.); physical losses (mass loss, texture loss and mechanical damages); biochemical changes (in: soluble solids content, titratable acidity, vitamin $\mathrm{C}$, phytochemicals etc.); and changes in enzymatic activities and pathological deterioration (diseases) (Yahia et al., 2011; Kahramanoğlu, 2017). Postharvest diseases are among the main causes of postharvest losses. For example, losses caused by Penicillium italicum and Penicillium digitatum in citrus fruits were reported to exceed $50 \%$ in the stored fruits in a single year (Feliziani and Romanazzi, 2013). Fungicides had been the most important tool for the management of postharvest diseases for many years, together with hygiene, cold storage and packaging. The most used active fungicide ingredients were imazalil, propiconazole and thiabendazole, which had been utilised for many years to control postharvest diseases, especially in citrus fruits (Kinay et al., 2007). However, the misuse and excessive use of fungicides induced the development of resistance in fungi and also threatened human health together with negative impacts on the environment (Koch et al., 2017; Ruffo Roberto et al., 2019). This then caused an increase in the global awareness of consumers about agro-chemicals, and the scientific world turned its attention to more humane and environmentally friendly alternatives (Palou et al., 2008). The major decay-causing disease organisms which damage fruits are blue mould (P. italicum) and green mould ( $P$. digitatum) in citrus fruits, pome fruits, stone fruits, grapes and berries; grey mould (Botrytis cinerea) in pome fruits, stone fruits, grapes and berries; alternaria rot (Alternaria spp.) in pome fruits and stone fruits; anthracnose (Colletotrichum spp.) in apples, avocados, bananas and mangoes; and brown rot (Monilia fructiocola) in apples, apricots, peaches and nectarines (Hardenburg et al., 1986; Thompson, 2008; Yahia et al., 2011; Madbouly et al., 2020).

The most important alternatives to fungicides include hot water treatments $\left(48-55^{\circ} \mathrm{C}\right.$ for $\left.2-5 \mathrm{~min}\right)$ (Kahramanoğlu et al., 2020), light irradiation (Papoutsis et al., 2019), protein hydrolysates (Lachhab et al., 2015), modified atmosphere packaging (Kahramanoğlu and Wan, 2020) and edible films (EF)/edible coatings (EC) with plant natural products (Riva et al., 2020). Ferreira et al. (2016) reported that over 50\% of the food in European countries is packed in plastics, which are dangerous for the environment due to their intrinsic long-lasting characteristics. On the other hand, EF and coating derived from plant-based natural products, including natural polymers (proteins, polysaccharides and lipids) and plant-derived secondary metabolites (i.e. essential oils), have been reported to have a very important role in fruit storage (Abdel-Rahim and Abo-Elyousr, 2017;
Chen et al., 2019; Ju et al., 2019; Riva et al., 2020). These materials are environmentally friendly with high biodegradability (Nor and Ding, 2020) and correct use of them may have no negative impacts on human health. Harvested fruits are alive and they continue to respire and transpire during storage. Both of these metabolic activities cause fruits to deteriorate. Most of the tropical and subtropical fruits contain superficial cuticle, which helps fruits to regulate respiration and transpiration and protects them against microbial decay. However, the waxy cuticle generally gets removed or damaged during washing or other handling practices. Therefore, the application of protective coatings (including wax) has been used in the fruit industry since the twelfth century, not only against microbial decay but also to prevent physiological changes, physical losses and biochemical changes (Yahia et al., 2011). Thus, the application of EF and other protective coatings serves the same role as the application of waxes and helps to reduce postharvest losses. The potential impact of the $\mathrm{EC} / \mathrm{EF}$ derived from natural plant-based products is significantly related to their ability to form a barrier over the fruit surface, and thus their usefulness in reducing the movement of atmospheric gases and water vapour (Ncama et al., 2018). Besides, natural plantbased products may have the ability to retard ethylene production, reduce the activity of free radicals and oxidation, and prevent enzymatic degradation and prevent/induce physiological changes (Ali et al., 2019; Maringgal et al., 2020). Moreover, another important characteristic of natural plant-based products is their hydrophobic potential, which provides antimicrobial activity. Besides, the antimicrobial activity of natural plant-based products can be explained with two separate mechanisms as follows: (a) direct prevention of the disease by inducing some biochemical reactions in pathogens and (b) indirect prevention of diseases by improving the product's tolerance to pathogens (Kahramanoğlu et al., 2020). There are numerous research and review articles available concerning the potential effects of natural plant-based products on the physical, physiological, biochemical and mechanical quality of stored fruits (Ncama et al., 2018; Parreidt et al., 2018; Kubheka et al., 2020; Kahramanoğlu et al., 2020; Riva et al., 2020); however, review studies with postharvest diseases are limited. Therefore, it was aimed in this review paper to summarise and discuss the potential effects of natural plant-based products on the postharvest disease in fruits.

\section{MAIN POSTHARVEST PHYTOPATHOGENS OF FRUITS}

Numerous phytopathogens cause damages to fruits after harvest. A few of them are very important and have a wide host range. The most important postharvest fungi are given in Table 1 and discussed in this section. 
Table 1. Main postharvest fungi in fruits.

\begin{tabular}{|c|c|c|c|c|}
\hline Common names & Latin names & Main host crops & Main damages/symptoms & References \\
\hline $\begin{array}{l}\text { Blue mould } \\
\text { Green mould }\end{array}$ & $\begin{array}{l}\text { Penicillium italicum } \\
\text { Penicillium digitatum }\end{array}$ & $\begin{array}{l}\text { Citrus species, guava, } \\
\text { mango, pome fruits, stone } \\
\text { fruits, grapes and berries }\end{array}$ & $\begin{array}{l}\text { Blue or green mould; fruit decay; } \\
\text { softens fruits and causes rapid } \\
\text { senescence }\end{array}$ & $\begin{array}{l}\text { (Palou, 2014; CABI, } \\
\text { 2021a, 2021b Palou, } \\
\text { 2014) }\end{array}$ \\
\hline Grey mould & Botrytis cinerea & $\begin{array}{l}\text { Pome fruits, stone fruits, } \\
\text { grapes and berries }\end{array}$ & $\begin{array}{l}\text { Soft rotting; prolific grey conidio- } \\
\text { phores with collapsed and water- } \\
\text { soaked parenchyma tissues occur }\end{array}$ & $\begin{array}{l}\text { (Abdel-Rahim and } \\
\text { Abo-Elyousr, 2017; } \\
\text { Williamson et al., 2007) }\end{array}$ \\
\hline Alternaria rot & Alternaria spp. & $\begin{array}{l}\text { Pome fruits and stone } \\
\text { fruits }\end{array}$ & $\begin{array}{l}\text { Grey, green and/or black spore } \\
\text { colonies and spots on fruits; } \\
\text { sunken lesions; over-ripe and } \\
\text { softer fruits }\end{array}$ & $\begin{array}{l}\text { (Aschehoug et al., 2012; } \\
\text { Nowicki et al., 2012) }\end{array}$ \\
\hline Anthracnose & Colletotrichum spp. & $\begin{array}{l}\text { Apples, avocados, } \\
\text { bananas, mangoes and } \\
\text { temperate fruits }\end{array}$ & Brown lesions; microbial decay & $\begin{array}{l}\text { (Thomidis, 2014; } \\
\text { Shivas et al., 2016) }\end{array}$ \\
\hline Brown rot & Monilia fructiocola & $\begin{array}{l}\text { Apricots, apples, pears, } \\
\text { quinces, peaches, nec- } \\
\text { tarines, other stone and } \\
\text { pome fruits }\end{array}$ & $\begin{array}{l}\text { Brown rot; blossom blight; can- } \\
\text { kers; fruit rots }\end{array}$ & $\begin{array}{l}\text { (Martini and Mari, } \\
\text { 2014; Uysal-Morca and } \\
\text { Kinay-Teksür, 2019) }\end{array}$ \\
\hline
\end{tabular}

\section{Blue mould (P. italicum) and green mould (P. digitatum) in citrus fruits, pome fruits, stone fruits, grapes and berries}

The genus name Penicillium is located in the Ascomycota division of fungi (CABI, 2021a). Blue and green moulds, which are caused by the $P$. italicum and $P$. digitatum, respectively, have been considered as the most important pathogens which cause the highest economic postharvest losses in citrus fruits. These are wound pathogens, which can infect the fruits that are at the preharvest stage in the field and/or at the postharvest stage during handling, packaging or storage in cold rooms. $P$. digitatum is the first of the Penicillium species whose complete genome was entirely sequenced (Palou, 2014). Both of the species were reported to be a problem in many countries in the continents of Africa, Asia, Europe, North America, South America and Oceania (CABI, 2021a, 2021b).

Both of the fungi may enter into the fruits from the mechanical damages during harvest or handling and can spread from fruit to fruit. On the other hand, the stem end of the fruits is an important entry point for all Penicillium species (Ladeniya, 2008). The optimum temperatures are between $20^{\circ} \mathrm{C}$ and $25^{\circ} \mathrm{C}$, where the growth of the fungi significantly slows below $5{ }^{\circ} \mathrm{C}$ or above $30^{\circ} \mathrm{C}$ (El-Otmani et al., 2011). Besides their decay damages, both of these fungi produce quite an amount of ethylene and may cause rapid senescence of nearby fruits. P. italicum is more problematic for fruits since it can spread in the package. This fungus is a nestingtype; it produces enzymes and softens the nearby fruit. On the contrary, $P$. digitatum is not a nesting-type and it is difficult for it to infect adjacent fruits. Since it may infect the fruits during preharvest or postharvest, both orchard and pack house sanitation are significantly important. Benomyl, imazalil, propiconazole and thiabendazole are among the most used fungicides against Penicillium rots in citrus fruits (Ladeniya, 2008; Abo-Elyousr et al., 2021).

\section{Grey mould (caused by B. cinerea) on pome fruits, stone fruits, grapes and berries}

This is a necrotrophic (kills host cells and uses the nutrients for its own growth) and airborne fungus which is reported to affect many plant species, mostly pome fruits, stone fruits, grapes and berries, and attacking more than 200 crops (Williamson et al., 2007). It can cause soft rotting not only on the fruits, but also on the aerial plant parts, including vegetables. It mostly causes damage on the mature tissues of plants, but its entry into the host takes place during the early states when the tissues are young. Thus, the main damages caused by $B$. cinerea occur after harvest during storage (AbdelRahim and Abo-Elyousr, 2017). Besides, massive losses may occur in the fields, especially in greenhouse crops before harvest (Staats et al., 2007). The fungus has a diverse mode of attack and survival ability as conidia or mycelia. Because of these characteristics, a single measure alone cannot be effective in controlling this fungus. The symptoms of the fungus can vary widely, where soft rots together with collapse and water-soaked parenchyma tissues occur. This is generally followed by grey masses of conidia as the most common symptom (Williamson et al., 2007). These symptoms adversely impact the marketability of the products. Some of the active ingredients of the fungicides against $B$. cinereae are thiram, mancozeb and captan. However, recent studies suggest that there are some resistant genotypes against captan or others. Studies also suggest that dicarboximides are effective against $B$. cinerea while its target sites are both conidia and mycelium (Leroux, 2004). A broad-spectrum fungicide, strobilurin, has also 
been reported to be effective by inhibiting cytochrome $\mathrm{b}$, while the other biosynthesis-inhibiting fungicide, fenhexamid, has also been reported to be effective. However, due to the problems of resistance, none of them could provide optimal efficacy (De Waard et al., 2006). Besides the chemical control, as for all other diseases, control of the environmental conditions could help to manage $B$. cinerea. It is well known that this fungus prefers high humidity, moderate temperature and reduced light. Therefore, management of these environmental conditions would help to improve crops' and/or products' resistance against the fungi. Several studies recommend that there are some other alternatives to fungicides, i.e. salts against $B$. cinerea (Youssef et al., 2019, 2020).

\section{Alternaria rot (caused by Alternaria spp.) on pome fruits and stone fruits}

Alternaria spp. is a broad genus of fungi that includes several major plant pathogenic species. They are also known to grow indoors and cause some allergens on human beings. The spores of Alternaria spp. are airborne and have been commonly found on plant wastes, soil and water. The Alternaria spp. colonies can be in very different colours, including grey, green and black. According to Nowicki et al. (2012), Alternaria spp. is responsible for approximately $20 \%$ of the spoilage in horticultural crops, which may reach up to $80 \%$ in some conditions. However, it is also known that some of the Alternaria spp. are beneficial, while they can be used as biocontrol agents against some invasive weeds (Aschehoug et al., 2012). One of the most common species of Alternaria is the Alternaria alternata, which can asexually propagate from its spores, named conidia (Timmer et al., 2003). A. alternata is the main cause of black spots on harvested fruits, which develop during storage (under favourable conditions) and damage the marketability of the products. It is also the main cause of black rot in cherry tomatoes, fruit spot on apples, brown spot on mandarins, fruit rot on capsicum, black heart on pomegranate, stem-end rot on mango and late blight on pistachios (Troncoso-Rojas and Tiznado-Hernández, 2014; Kahramanoğlu et al., 2018). Besides the chemical treatments, heat treatment and natural plant-based products can be used (Troncoso-Rojas and TiznadoHernández, 2014). It can grow in extreme conditions, but prefers free moisture and a temperature of around $20-25^{\circ} \mathrm{C}$ (Timmer et al., 2003).

\section{Anthracnose (Colletotrichum spp.) on apple, avocado, banana, mango and other temperate fruits}

Colletotrichum spp. is among the most important phytopathogens. It is reported to include more than 200 species in its genera (Marin-Felix et al., 2017). Some species of Colletotrichum spp. cause anthracnose and damage many tropical and subtropical fruits (Shivas et al., 2016). Anthracnose significantly reduces the marketability of stored fruits. It damages anthracnose, and so the symptoms may appear on fruits, and also on the flowers, leaves and branches of several horticultural crops. Its symptoms begin as tiny rounded leaf spots with yellow halos on the leaves and become chlorotic, which may lead to premature defoliation. On the other hand, symptoms on the fruits commonly appear as brown lesions, which results in microbial decay in the fruits. The spores may appear in grey to orange colours, and these turn into lesions in mature fruits (Thomidis, 2014). The spores of the fungus may easily grow and develop on crops and disperse with water splashes to other plant parts, causing a secondary inoculum. High moisture (varying from $62 \%$ to $95 \%$ ) with a temperature of 20-30 ${ }^{\circ} \mathrm{C}$ favours the dispersal of the conidia (Cannon et al., 2012). Some of the major fruits affected by anthracnose are avocado, strawberry, banana, peach, apple, grape, mango, citrus, pomegranate and guava. It may cause premature fall in citrus fruits, especially during the rainy seasons and during bloom (Silva and Michereff, 2013; Xavier et al., 2019).

\section{Brown rot (M. fructiocola) on apricots, peach and nectarine}

Another important fungal pathogen which causes brown rot, especially in the stone fruits, is Monilinia spp. belonging to the Helotiales order. According to Martini and Mari (2014), the estimated economic loss around the world is approximately $1.7 \mathrm{M} € \cdot$ year $^{-1}$. The three main species of this genus are Monilinia fructicola, Monilinia fructigena and Monilinia laxa. The phytopathogens are known to begin infections on the above-ground plant parts with several different types of symptoms, including cankers on elder tissues, blighting of blossoms and, most importantly for us, the fruit rots. Some pre- and postharvest fungicides were reported to be effective for the regular control of brown rot, but as described before, the consumer preferences have led to demand for alternatives in management of the disease (Uysal-Morca and Kinay-Teksür, 2019). The brown rot fungus is ascomycetes and can produce sexual spores (ascospores). The wet season favours its growth and development. Besides, warm climates also stimulate the growth and development of brown rot. The damage mainly starts at the tree, as the formation of blights in blossoms and/or twigs is accompanied with soft decay in fruits, most commonly peaches, plums and cherries and rarely on apples and pears. Increase in the sugar content of the fruits, just before harvest, increases the susceptibility of the fruits to brown rot. Therefore, the unripe, green fruits are more tolerant to brown rot. Therefore, starting from the site selection (orchard location), continuing with the cultural practices and pre- and postharvest treatments, we infer that these are all together important for the management of brown rot. Alternatives to chemical treatments are undergoing research, where the antagonistic isolates of Bacillus and Pseudomonas spp. 
were noted to provide success in controlling brown rot after harvest (Ritchie, 2000).

\section{PLANT-BASED NATURAL PRODUCTS FOR CONTROLLING POSTHARVEST PHYTOPATHOGENS}

$\mathrm{EC}$ are thin layers of coating materials derived from the edible biomaterials on fruits, vegetables or other food products, whereas EF are thin layers of the same materials (McHugh, 2000). The applications of these two also differ from each other and can be the main difference among them. EC are applied in liquid form by dipping the fruits into the solutions, whereas EF are produced from biomaterials such as solid sheets, and the fruits are covered/packed/ wrapped with these films. The most important benefit of these materials is that they create a modified atmosphere around the fruits and prevent the transfer of gases and water vapour, resulting in a reduction in the respiration and transpiration rates (Falguera et al., 2011). Currently, $\mathrm{EF}$ and coatings derived from natural plant-based products are highly used in the food packaging industry. These materials provide several benefits in postharvest fruit storage, including prevention of microbial decay, reducing mass loss, improving appearance and texture, protection of the phytochemicals and biochemical quality (Ncama et al., 2018; Kahramanoğlu et al., 2020). In this section, the three most important groups (proteins, polysaccharides and lipids) and the secondary metabolites of plant-based products used for the production of EC and EF are discussed.

\section{Natural plant-based products that are protein-based}

Proteins are biomaterials formed by amino acids. In total, 20 amino acids have been identified till today, and numerous of them are attached to each other in long chains and form as proteins. Hydrolysis (cleavage of a covalent bond) can be used to release amino acids from the proteins. Proteins have been used to produce $\mathrm{EF}$ or EC to preserve fruits and vegetables (Baldwin et al., 2011).

\section{Wheat gluten}

Wheat gluten is a food produced from the main protein (gluten) of wheat. It is composed of charged amino acids (lysine, histidine and arginine) in a lesser proportion, while more of it is composed of non-polar amino acids. They come together for hydrophobic interactions. According to the solubility of the proteins, they can be grouped into four primary fractions: water soluble (albumins), soluble in dilute salt solutions (globulins), soluble in ethanol (gliadins) and insoluble (glutenin) (Chism and Haard, 1996). Wheat gluten has moderate elasticity and cohesiveness abilities but plasticisers with glycerin have been reported to be used for enhancing the flexibility of the coatings or films (Gennadios et al., 1994).

\section{Corn zein}

Compared to other proteins, corn zein protein has some special characteristics. Zein has higher percentages of non-polar amino acids and low percentages of other elements. The most abundant amino acids of corn zein protein are glutamine, leucine and proline. The corn zein is thus insoluble in water. Among the constituents of corn zein, the alpha-zein fractions are soluble in $95 \%$ ethanol, whereas the beta-zein fractions are soluble in $60 \%$ ethanol (Shukla and Cheryan, 2001). Corn zein is of hydrophobic nature and has a good film-forming characteristic (Gennadios et al., 1994). It has a very good ability to block the transport of moisture and prevent transpiration (Hassan et al., 2018).

\section{Soy protein}

Soy protein is isolated from soybeans. Beta-conglycinin and glycinin compromise approximately $37 \%$ and $41 \%$ of the soy proteins (Kunte et al., 1997). Glycinin has a film-forming ability, which is used as an emulsifier or gelling agent (Subirade et al., 1998). The film formation of soy protein is significantly affected by alkaline conditions and heat. Beta-conglycinin is less heat stable than glycinin (Renkema and Van Vliet, 2002). In a recent study, it was noted that the combination of soybean protein isolate with cinnamaldehyde provided higher efficacy for improving the storability of banana fruits, while it reduced the fungal decay of the fruits $(\mathrm{Li}$ et al., 2019).

\section{Natural plant-based products that are lipid-based}

Lipids are biomolecules that include hydrocarbons and make up the building blocks of the structure and function of living cells. They include hydrophobic (water-repellent) compounds which are insoluble in water and soluble in non-polar solvents. Fats, oils, waxes and some vitamins (i.e. A, D, E and K) are some examples of lipids (Baldwin et al., 2011). The fragile characteristic of the lipids makes it necessary for them to be commonly incorporated with other compounds, such as polysaccharides (Donhowe, 1994). Oils and waxes are the most important lipids used in food preservation. Besides, dispersion of oils or waxes in water or other hydrophilic solutions is also known as emulsion coating (Baldwin et al., 2011).

\section{Oils}

Oils are made up of carbon $(\mathrm{C})$, hydrogen $(\mathrm{H})$ and oxygen (O) and are mainly composed of unsaturated (double or triple bonds among carbon-to-carbon) fatty acids which makes them liquid at room temperature. Several different types of oils, including essential oils, mineral oils, rapeseed oil and vegetable oils (peanut, corn and soy) have been used in food packaging (Baldwin et al., 2011). The most widely known fatty acids are palmitic acid (16-carbon fatty acids) and stearic acid (16-carbon fatty acids). Stearic acid is very common in vegetable oils, including cocoa oil. Other important fatty acids are 
palmitoleic acid, oleic acid and linoleic acid (Srivastava, 2002). In a most recent study, Bahadırlı et al. (2020) recommended that the essential oils of myrtle leaves (with $39.38 \%$ of eucalyptol) have the ability to prevent decay incidence in loquat fruits. In a different study, Jahani et al. (2020) confirmed that the application of eucalyptus, galbanum and clove oil provides a higher ability to control Aspergillus niger in pomegranate fruits. The success with different oils was reported by several other studies, such as Mentha longifolia oil for controlling anthracnose (Colletotrichum spp. nymphaeae) in strawberry fruits (Hosseni et al., 2020); lemon, orange and mandarin oil for controlling B. cinerea in strawberry fruits (Shehata et al., 2020); and black seed, lemon and clove oils for controlling fungi in cucumber fruits (Mossa et al., 2021).

\section{Waxes}

Plant waxes are among the most common natural plantbased products used in postharvest handling practices, which are commonly found as granular or continuous layers that form outside or within the cuticle of many above-ground plant parts (Lan, 2019). They generally have waterproofing ability in the amorphous layer of the plant outer surface. Most common plant waxes are candelilla (Euphorbia antisyphilitica) wax, carnauba (Copernicia cerifera) wax and sunflower (Helianthus annuus) wax (Agrios, 2005). Carnauba wax coating was also reported to control fungal pathogens in mangosteen fruits (Castro et al., 2012).

\section{Natural plant-based products that are polysaccharide-based}

Polysaccharides obtained from animals (chitin and chitosan) or plants (cellulose, pectin, gum polymers, starch, Aloe vera etc.) are available in large quantities in nature, and these are complex carbohydrates with glycosidic bonds (Thakur and Thakur, 2016; Khalil Bagy et al., 2020). Polysaccharides have the ability to produce biodegradable films, which have advantages in food storage since they are capable of controlling gaseous composition, respiration and transpiration of the fresh produce (Freitas et al., 2014). Polysaccharidebased materials, EF/EC, provide good barrier against oxygen and carbon dioxide, but have a low ability to control water vapour, because of their hydrophilic characteristics (Rhim et al., 2013).

\section{Cellulose}

Cellulose is found in the cell walls of plants and so is among the most abundant polymers in the biosphere. It has the ability to form fibres with strong hydrogen bonds, which makes it a suitable material for papers and corrugated packages (Babu et al., 2013). Cellulose is commonly produced from sugarcane, cotton fibres and wood. Besides its biodegradability, it has low density, high mechanical strength and film-forming characteristics (Credou and Berthelot, 2014). Cellulosederived $\mathrm{EC}$ and $\mathrm{EF}$ are transparent, hydrophilic and odourless and they have a moderate ability for oxygen and gaseous transfer (Hassan et al., 2018).

\section{Starch}

Most plants (such as wheat, corn, rice, potatoes, manioc, amaranth and cashew) store energy as starch, which is a type of carbohydrate, consisting of carbon, hydrogen and oxygen atoms (Babu et al., 2013). Starch is composed of amylose (linear) and amylopectin (branched) polymers and is insoluble in cold. The most important characteristic of starch polymers is its ability of forming coatings with low oxygen permeability. It also has high hydrophilic ability and low flexibility (Ortega-Toro et al., 2015). To improve its flexibility, plasticisers (such as glycerol and sorbitol) are commonly used (Müller et al., 2008). Studies with EC developed from rice starch with sucrose esters showed that coatings are highly effective in delaying ethylene biosynthesis and senescence (Thakur et al., 2019). Although no studies were tested on diseases in the current research, it is well known that delaying the senescence improves the fruits' resistance against phytopathogens. The EC produced from the kernel starch of mango fruits was reported to have the ability to enhance the shelf-life of tomato fruits and prevent fungal decay at the same time (Nawab et al., 2017).

\section{Pectin}

Pectin (heteropolysaccharide) is a type of starch which is naturally produced in the cell walls of fruits and vegetables; it is mostly included also in the peels of citrus fruits or apple pomace (Pérez et al., 2003). Pectin has a gelling characteristic with the ability to maintain low moisture (Liu et al., 2007) and control of phytopathogens. Valdes et al. (2015) recommended that pectin films are now used for the storage of several fruits including peach, guava, apples, apricot and berries. Coatings prepared with a combination of pectin $(0.16 \% \mathrm{w} / \mathrm{v})$, candelilla wax, glycerol and Larrea tridentata leaves extract were reported to reduce the disease severity of avocado fruits caused by Colletotrichum spp. gleosporioides and $A$. alternata (Aguirre-Joya et al., 2019).

\section{$A$. vera polysaccharides}

A. vera is a good source of polysaccharides. Besides the film-forming abilities of A. vera, it is also known to have high antimicrobial ability to control fungi, bacteria and viruses (Kahramanoğlu et al., 2019). Nabigol and Asghari (2013) suggest that $500 \mathrm{~mL} \cdot \mathrm{L}^{-1}$ dose of $A$. vera gel provides $100 \%$ control of $P$. digitatum and $64 \%$ of A. niger. Besides, several concentrations of $A$. vera gel $(20 \%, 60 \%$ and $100 \%)$ were noted to have a high ability to prevent phytopathogenic decay in tomato fruits (Kator et al., 2018). A. vera gel was also noted to be effective in preventing the growth of Botrytis gladiolorum and Penicillium gladioli (Rosca-Casian et al., 2007). Similar to other biomaterials, combinations of some might improve the performance of the materials. As a support to this information, it was noted that the combination of $A$. vera with thymol has a higher ability to prevent 
fruit decay at nectarines caused by Rhizopus stolonifer, B. cinerea and P. digitatum (Navarro et al., 2011).

\section{Plant gums}

Plant gums are complex polymers of carbohydrates which may include proteins or other components. Gummosis is the release process of plant gums mainly in response to environmental stress conditions, including mechanical injuries. They are very common in commercial horticultural crops, and are most commonly found in citrus crops and Prunus spp. (including plums, apricots, cherry and peach) and some species of the Fabaceae family (Patten et al., 2010). Some of the most important plant gums are: guar gum, a ground endosperm of guar seed from the guar tree (Cyamopsis tetragonoloba); tara gum, from the endosperm of seeds from the tara tree (Cesalpinia spinosa L.), carob (locust) bean gum, from the endosperm of carob tree (Ceratonia siliqua) seeds; Arabic gum, an exudate from the stems of Acacia spp. trees; and plum gum, extracted from the plum tree (Prunus domestica) (Nieto, 2009). The locust bean gum, incorporated with pomegranate peel extract was noted as an effective method for reducing the $P$. digitatum in orange fruits (Kharchoufi et al., 2018). Arabic gum and almond gum applications to fruits were reported to reduce the respiration rate and ethylene production, which improves the products resistant to phytopathogens and delays the fruit senescence (Mahfoudhi and Hamdi, 2015). The use of Arabic gum was also reported to improve the storability of bananas and papayas (Maqbool et al., 2011). Studies with a combination of Arabic gum and ginger oil resulted in an inhibition of $C$. gloeosporioides growth on papaya fruits (Ali et al., 2016). Similarly, the combination of Arabic gum with thyme oil, both at $1 \%$ concentration, resulted in the prevention of fungal decay in avocado fruits (Bill et al., 2014).

Table 2. Natural plant-based products for controlling postharvest phytopathogens.

\begin{tabular}{|c|c|c|c|}
\hline Main groups & Sub-groups & $\begin{array}{l}\text { Important features and main advantages } \\
\text { in postharvest handling }\end{array}$ & References \\
\hline \multirow[t]{3}{*}{ Proteins } & Wheat gluten & $\begin{array}{l}\text { Insoluble in neutral solvents. Has moderate } \\
\text { elasticity and cohesiveness abilities. Provides } \\
\text { barrier to water vapour. }\end{array}$ & (Gennadios et al., 1994) \\
\hline & Corn zein & $\begin{array}{l}\text { Insoluble in water. Has a hydrophobic nature } \\
\text { and exhibits a good film-forming characteristic. } \\
\text { Blocks the transport of moisture and prevents } \\
\text { transpiration. }\end{array}$ & (Hassan et al., 2018) \\
\hline & Soy protein & $\begin{array}{l}\text { Insoluble in water. Has film-forming ability for } \\
\text { blocking moisture transfer. }\end{array}$ & (Renkema and Van Vliet, 2002) \\
\hline \multirow[t]{2}{*}{ Lipids } & Oils & $\begin{array}{l}\text { Insoluble in water. Provides barrier against } \\
\text { atmospheric gases and water vapour. Also has } \\
\text { direct and indirect impact on fungi. }\end{array}$ & $\begin{array}{l}\text { (Bahadırlı et al., 2020; Mossa } \\
\text { et al., 2021) }\end{array}$ \\
\hline & Waxes & $\begin{array}{l}\text { Most common products in postharvest handling. } \\
\text { Has high waterproofing ability. Prevents } \\
\text { respiration, transpiration and fungal infections. }\end{array}$ & (Castro et al., 2012; Lan, 2019) \\
\hline \multirow[t]{5}{*}{ Polysaccharides } & Cellulose & $\begin{array}{l}\text { Has low density, high mechanical strength and } \\
\text { film-forming characteristics. It has moderate } \\
\text { ability for oxygen and gaseous transfer. }\end{array}$ & $\begin{array}{l}\text { (Credou and Berthelot, 2014; } \\
\text { Hassan et al., 2018) }\end{array}$ \\
\hline & Starch & $\begin{array}{l}\text { Insoluble in cold water. Has low oxygen } \\
\text { permeability but low flexibility. Delays } \\
\text { ethylene biosynthesis and the fruit senescence. }\end{array}$ & $\begin{array}{l}\text { (Ortega-Toro et al., 2015; Thakur } \\
\text { et al., 2019) }\end{array}$ \\
\hline & Pectin & $\begin{array}{l}\text { Has a gelling characteristic with ability } \\
\text { to maintain low moisture and controls } \\
\text { phytopathogens. }\end{array}$ & $\begin{array}{l}\text { (Liu et al., 2007; Aguirre-Joya } \\
\text { et al., 2019) }\end{array}$ \\
\hline & Aloe vera & $\begin{array}{l}\text { Has high film-forming ability and high } \\
\text { antifungal characteristics. }\end{array}$ & $\begin{array}{l}\text { (Navarro et al., 2011; } \\
\text { Kahramanoğlu et al., 2019) }\end{array}$ \\
\hline & Plant gums & $\begin{array}{l}\text { They have the ability to reduce the respiration } \\
\text { rate and ethylene production, improve the } \\
\text { resistance of products to phytopathogens and } \\
\text { delay the fruit senescence. }\end{array}$ & (Mahfoudhi and Hamdi, 2015) \\
\hline $\begin{array}{l}\text { Secondary } \\
\text { metabolites }\end{array}$ & $\begin{array}{l}\text { Citral, eugenol, } \\
\text { thymol etc. }\end{array}$ & $\begin{array}{l}\text { They may have direct or indirect antifungal } \\
\text { activity (by improving products' tolerance or } \\
\text { damaging fungi). }\end{array}$ & $\begin{array}{l}\text { (Wei et al., 2021; Yang et al., } \\
\text { 2021) }\end{array}$ \\
\hline
\end{tabular}




\section{Plant-originated secondary metabolites}

Besides the above-described primary products (metabolites) of plants, numerous studies have suggested that phytochemicals (secondary metabolites) isolated from plants can be used to control many phytopathogens, including thymol (Pérez-Alfonso et al., 2012), pinocembrin (Chen et al., 2020), citral (Wei et al., 2021) and alkaloids (Musto et al., 2014) isolated from plant sources, extracts or essential oils (Moraes Bazioli et al., 2019). In a very recent study, Yang et al. (2021) noted that the cinnamaldehyde, eugenol and carvacrol nanoemulsion have a high ability to reduce the decay of citrus fruits caused by $P$. digitatum. In another study, Annona muricata fruit extracts were reported to have the ability to alternatively control Alternaria spp. spots in tomato fruit. The in vitro assays with $6 \%$ of methanol extracts of the seeds were found to have approximately $90 \%$ inhibition of radial mycelial growth of $A$. alternata, whereas the in vivo studies resulted in $84 \%$ disease inhibition (Rizwana et al., 2021). Besides, canola and mustard extracts were reported to have a significant influence on the prevention of the development of $P$. digitatum in oranges. It was suggested that this efficacy is a result of the volatile compounds of the extracts (Koltz et al., 2020). EC and EF incorporated with plant extracts (Fantasia japonica) can be used to control P. italicum disease in citrus fruits (Liu et al., 2017).

\section{CONCLUSIONS}

Discussion of the existing literature has suggested that protein-, lipid- and polysaccharide-based EC and EF, and other secondary plant metabolites, have important abilities to control postharvest phytopathogens together with the improved storability of fruits (Table 2). These naturally occurring biomaterials are healthy and biodegradable. In addition, they are edible, including some essential nutrients having an important role in the human diet. The main advantages of these natural plantbased products are that they provide a barrier at the outer surface of fruits against water vapour and gases, and result in reduced respiration and transpiration. Moreover, the fruit senescence is delayed and the healthy fruits are more resistant to postharvest diseases. Besides, some of these natural plant-based products, especially oils and secondary plant metabolites, have the ability to directly control some phytopathogens or indirectly induce fruit resistance against diseases by activating fruits' defence mechanisms (Kahramanoğlu et al., 2020). Although there are some commercial EC and EF available in the market, it is still necessary to conduct more studies, mainly about the costs of their bulk production and use. The commercial development of EC and EF, and increasing their use in postharvest fruit preservation, will provide significant benefits not only in the field of fruit storage but also for sustainable production and environmental protection.

\section{FUNDING}

This research was funded by the Natural Science Foundation in Jiangxi Province, China (20181BCB24005).

\section{AUTHOR CONTRIBUTIONS}

Ch.W. - conceptualization, writing-reviewing and editing. İ.K. - conceptualization, investigation, writing original draft preparation. V.O. - conceptualization, writing-reviewing and editing, visualization.

\section{CONFLICT OF INTEREST}

Authors declare no conflict of interest.

\section{REFERENCES}

Abdel-Rahim, I. R., and Abo-Elyousr, K. A. M. (2017). Using of endophytic Saccharomycopsis fibuligera and thyme oil for management of gray mold rot of guava fruits. Biological Control, 110, 124-131, doi: 10.1016/j.biocontrol.2017.04.014.

Abo-Elyousr, K. A., Al-Qurashi, A. D., And Almasoudi, N. M. (2021). Evaluation of the synergy between Schwanniomyces vanrijiae and propolis in the control of Penicillium digitatum on lemons. Egyptian Journal of Biological Pest Control, 31(1), 1-10, doi: 10.1186/s41938-021-00415-4.

Agrios, G. N. (2005). How pathogens attack plants? In G. Agrios (Ed.), Plant pathology (pp. 175-205), Academic Press. doi: 10.1016/B978-0-08-0473789.50011-7.

Aguirre-joya, J. A., Cerqueira, M. A., VenturaSobrevilla, J., Aguilar-Gonzalez, M. A., CarbóArgibay, E., Castro, L. P., and Aguilar, C. N. (2019). Candelilla wax-based coatings and films: Functional and physicochemical characterization. Food and Bioprocess Technology, 12(10), 1787-1797, doi: 10.1007/s11947-019-02339-2.

Ali, A., Hei, G. K., and Keat, Y. W. (2016). Efficacy of ginger oil and extract combined with gum Arabic on anthracnose and quality of papaya fruit during cold storage. Journal of Food Science and Technology, 53(3), 1435-1444, doi: 10.1007/s13197-015-2124-5.

Ali, S., Khan, A. S., Nawaz, A., Anjum, M. A., Naz, S., Euaz, S., And Hussain, S. (2019). Aloe vera gel coating delays postharvest browning and maintains the quality of harvested litchi fruit. Postharvest Biology and Technology, 157, 110960, doi: 10.1016/j. postharvbio.2019.110960.

Aschehoug, E. T., Metlen, K. L., Callaway, R. M., and Newcombe, G. (2012). Fungal endophytes directly increase the competitive effects of an invasive forb. Ecology, 93(1), 3-8, doi: 10.1890/11-1347.1.

Babu, R. P., O'connor, K., and Seeram, R. (2013). Current progress on bio-based polymers and their 
future trends. Progress in Biomaterials, 2(1), 1-16, doi: 10.1186/2194-0517-2-8.

Bahadirli, N. P., Kahramanoğlu, I., and Wan, C. (2020). Exposure to volatile essential oils of myrtle (Myrtus communis L.) leaves for improving the postharvest storability of fresh loquat fruits. Journal of Food Quality, 2020, 8857669, 10. doi: 10.1155/2020/8857669.

Baldwin, E. A., Hagenmaier, R., and Bai, J. (EDS.). (2011). Edible coatings and films to improve food quality. Boca Raton, Florida, USA: CRC Press.

Bill, M., Sivakumar, D., Korsten, L., and Thompson, A. K. (2014). The efficacy of combined application of edible coatings and thyme oil in inducing resistance components in avocado (Persea americana Mill.) against anthracnose during post-harvest storage. Crop Protection, 64, 159-167, doi: 10.1016/j. cropro.2014.06.015.

CABI (2021a). Penicillium digitatum (green mould). Retrieved from https://www.cabi.org/isc/ datasheet/39570 (accessed on 22 March 2021).

CABI (2021b). Penicillium italicum (blue mould). Retrieved from https://www.cabi.org/isc/ datasheet/39581 (accessed on 22 March 2021).

Cannon, P. F., Damm, U., Johnston, P. R., and Weir, B. S. (2012). Colletotrichum - current status and future directions. Studies in Mycology, 73, 181-213, doi: 10.3114/sim0014

Castro, M. F. P. P. M. D., Anjos, V. D. D. A., Rezende, A. C. B., Benato, E. A., and Valentini, S. R. D. T. (2012). Postharvest technologies for mangosteen (Garcinia mangostana L.) conservation. Food Science and Technology, 32(4), 668-672, doi: 10.1590/S0101-20612012005000103.

Chen, C., Chen, J., And Wan, C. (2020). Pinocembrin7-glucoside (P7G) reduced postharvest blue mold of navel orange by suppressing Penicillium italicum growth. Microorganisms, 8(4), 536, doi: 10.3390/ microorganisms 8040536.

Chen, J., Shen, Y., Chen, C., And Wan, C. (2019). Inhibition of key citrus postharvest fungal strains by plant extracts in vitro and in vivo: A review. Plants, 8(2), 26. doi: 10.3390/plants8020026.

Chism, G. W., and HaArd, N. F. (1996). Characteristics of edible plant tissue. In O. W. Fennema (Ed.), Food chemistry (p. 1067). New York, NY, USA: Marcel Dekker.

Cole, M. B., Augustin, M. A., Robertson, M. J., And Manners, J. M. (2018). The science of food security. Science of Food, 2(1), 1-8, doi: 10.1038/s41538-0180021-9.

Credou, J., and Berthelot, T. (2014). Cellulose: from biocompatible to bioactive material. Journal of Materials Chemistry B, 2(30), 4767-4788. doi: 10.1039/C4TB00431K.

De Waard, M. A., Andrade, A. C., Hayashi, K., Schoonbeek, H., Stergiopoulos, I., And Zwiers, L. H. (2006). Impact of fungal drug transporters on fungicide sensitivity, multidrug resistance and virulence. Pest Management Science, 62, 195-207, doi: 10.1002/ps.1150.

Donhowe, I. G. (1994). Edible films and coatings: Characteristics, formation, definitions, and testing methods. In J. M. Krochta, E. A. Baldwin, and M. O. Nisperos-Carriedo (Eds), Edible coatings and films to improve food quality (pp. 1-24). Lancaster, PA, USA: Technomic Publishing Co.

El-Otmani, M., Ait-Oubahou, A., and Zacarías, L. (2011). Citrus spp.: Orange, mandarin, tangerine, clementine, grapefruit, pomelo, lemon and lime. In E. M. Yahia (Ed.), Postharvest biology and technology of tropical and subtropical fruits (pp. 437-516e). Cambridge, UK: Woodhead Publishing Limited.

Falguera, V., Quintero, J. P., Jiménez, A., Muñoz, J. A., AND IBARZ, A. (2011). Edible films and coatings: Structures, active functions and trends in their use. Trends in Food Science \& Technology, 22(6), 292 303, doi: 10.1016/j.tifs.2011.02.004.

FAO (2021). FAOSTAT Statistical Web Page. Retrieved from http://www.fao.org/faostat/en/\#data/QC (accessed on 21 March 2021).

Feliziani, E., And Romanazzi, G. (2013). Preharvest application of synthetic fungicides and alternative treatments to control postharvest decay of fruit. Stewart Postharvest Review, 9(3), 1-6. doi: 10.2212/ spr.2013.3.4.

Ferreira, A. R., Alves, V. D., And Coelhoso, I. M. (2016). Polysaccharide-based membranes in food packaging applications. Membranes, 6(2), 22, doi: 10.3390/membranes6020022.

Freitas, F., Alves, V. D., Reis, M. A., Crespo, J. G., And Coelhoso, I. M. (2014). Microbial polysaccharidebased membranes: Current and future applications. Journal of Applied Polymer Science, 131(6), doi: 10.1002/app.40047.

Gennadios, A., Weller, C. L., And Gooding, C. H. (1994). Measurement errors in water vapor permeability of highly permeable, hydrophilic edible films. Journal of Food Engineering, 21(4), 395-409, doi: 10.1016/0260-8774(94)90062-0.

Gunders, D. (2017). Wasted: How America is losing up to $40 \%$ of its food from farm to fork to landfill. Natural Resources Defense Council, 26, 1-26.

Hardenburg, R. E., Watada, A. E., And Wang, C. Y. (1986). The commercial storage of fruits, vegetables, and florist and nursery stocks (No. 66). US Department of Agriculture, Agricultural Research Service.

Hassan, B., Chatha, S. A. S., Hussain, A. I., Zia, K. M., AND Akhtar, N. (2018). Recent advances on polysaccharides, lipids and protein based edible films and coatings: A review. International Journal of Biological Macromolecules, 109, 1095-1107, doi: 10.1016/j.ijbiomac.2017.11.097.

Hosseni, S., Amini, J., Rafei, J. N., And Khorshidi, J. (2020). Management of strawberry anthracnose 
using plant essential oils as bio-fungicides, and evaluation of their effects on quality of strawberry fruit. Journal of Oleo Science, 69(4), 377-390, doi: 10.5650/jos.ess 19119 .

Jahani, M., Pira, M., And Aminifard, M. H. (2020). Antifungal effects of essential oils against Aspergillus niger in vitro and in vivo on pomegranate (Punica granatum) fruits. Scientia Horticulturae, 264, 109188, doi: 10.1016/j.scienta.2020.109188.

Ju, J., Xie, Y., Guo, Y., Cheng, Y., Qian, H., and Yao, W. (2019). Application of edible coating with essential oil in food preservation. Critical Reviews in Food Science and Nutrition, 59(15), 2467-2480, doi: 10.1080/10408398.2018.1456402.

KAHRAMANOĞLU, I. (2017). Introductory chapter: Postharvest physiology and technology of horticultural crops. In I. Kahramanoğlu (Ed.), Postharvest handling (pp. 1-5). InTechOpen. doi: 10.5772/intechopen.69466.

KahramanoĞlu, I., AND Wan, C. (2020). Determination and improvement of the postharvest storability of little mallow (Malva parviflora L.): A novel crop for a sustainable diet. HortScience, 55(8), 1378-1386, doi: 10.21273/HORTSCI15179-20.

Kahramanoŭlu, İ., Chen, C., Chen, J., and Wan, C. (2019). Chemical constituents, antimicrobial activity, and food preservative characteristics of Aloe vera gel. Agronomy, 9(12), 831, doi: 10.3390/ agronomy9120831.

KahramanoĞlu, I., Okatan, V., and Wan, C. (2020). Biochemical composition of propolis and its efficacy in maintaining postharvest storability of fresh fruits and vegetables. Journal of Food Quality, 2020, 8869624, doi: 10.1155/2020/8869624.

KahramanoĞlu, I., Usanmaz, S., Alas, T., Helvaci, M., AND Aşkin, A. (2018). Fungicides effect on the heart rot infestations at pomegranate fruit. International Journal of Agriculture Forestry and Life Sciences, 2(2), 1-5.

Kahramanoğlu, İ., Usanmaz, S., Alas, T., Okatan, V., AND Wan, C. (2020). Combined effect of hot water dipping and Cistus creticus L. leaf extracts on the storage quality of fresh Valencia oranges. Folia Horticulturae, 32(2), 337-350, doi: 10.2478/ fhort-2020-0029.

Kang, Y., Khan, S., AND MA, X. (2009). Climate change impacts on crop yield, crop water productivity and food security - A review. Progress in Natural Science, 19(12), 1665-1674, doi: 10.1016/j. pnsc.2009.08.001.

Kator, L., Hosea, Z. Y., And Ene, O. P. (2018). The efficacy of Aloe vera coating on postharvest shelf life and quality tomato fruits during storage. Asian Research Journal of Agriculture, 8(4), 2456-2561, doi: 10.9734/ARJA/2018/41540.

Khalil Bagy, H. M., Ibtesam, B. F., Abou-Zaid, E. A., Sabah, B. M., and Nashwa, S. M. (2020). Control of green mold disease using chitosan and its effect on orange properties during cold storage. Archives of Phytopathology and Plant Protection, 1-16, doi: 10.1080/03235408.2020.1847568.

Kharchoufi, S., Parafati, L., Licciardello, F., Muratore, G., Hamdi, M., Cirvilleri, G., And Restuccia, C. (2018). Edible coatings incorporating pomegranate peel extract and biocontrol yeast to reduce Penicillium digitatum postharvest decay of oranges. Food Microbiology, 74, 107-112, doi: 10.1016/j.fm.2018.03.011.

Kinay, P., Mansour, M. F., Gabler, F. M., Margosan, D. A., And Smilanick, J. L. (2007). Characterization of fungicide-resistant isolates of Penicillium digitatum collected in California. Crop Protection, 26(4), 647 656, doi: 10.1016/j.cropro.2006.06.002.

Koch, S., Epp, A., Lohmann, M., and Böl, G. F. (2017). Pesticide residues in food: attitudes, beliefs, and misconceptions among conventional and organic consumers. Journal of Food Protection, 80(12), 2083-2089, doi: 10.4315/0362-028X.JFP-17-104.

Koltz, E. A., Dos Santos, I., Dallemole-Giaretta, R., Pazolini, K., Leite, C. D., and Steilmann, P. (2020). Combining Brassica sachets and extracts with thermotherapy against postharvest green mold of orange. Scientia Horticulturae, 268, 109389, doi: 10.1016/j.scienta.2020.109389.

KubheKa, S. F., Tesfay, S. Z., Mditshwa, A., and MagwaZA, L. S. (2020). Evaluating the efficacy of edible coatings incorporated with moringa leaf extract on postharvest of 'Maluma' avocado fruit quality and its biofungicidal effect. HortScience, 55(4), 410-415, doi: 10.21273/HORTSCI14391-19.

Kunte, L. A., Gennadios, A., Cuppett, S. L., Hanna, M. A., And Weller, C. L. (1997). Cast films from soy protein isolates and fractions. Cereal Chemistry, 74(2), 115-118, doi: 10.1094/CCHEM.1997.74.2.115.

Lachiab, N., Sanzani, S. M., Fallanaj, F., Youssef, K., Nigro, F., Boselli, M., And Ippolito, A. (2015). Protein hydrolysates as resistance inducers for controlling green mould of citrus fruit. Acta Horticulture, 1065, 1593-1598, doi: 10.17660/ActaHortic.2015.1065.203.

LAdENIYA, M. S. (2008). Postharvest diseases and their management. In M. S. Ladeniya (Ed.), Citrus fruitBiology, technology and evaluation (pp. 417-449), XVIII-XIX, Academic Press. doi: 10.1016/B978012374130-1.50018-8.

LAN, Y. (2019). Waxes. Reference module in food science. Encyclopedia of Food Chemistry, 312-316, doi: 10.1016/B978-0-08-100596-5.22344-5.

Leroux, P. (2004) Chemical control of Botrytis and its resistance to chemical fungicides. In Y. Elad, B. Williamson, P. Tudzynski and N. Delen (Eds), Botrytis: Biology, pathology and control (pp. 195222). Dordrecht, The Netherlands: Kluwer Academic Press.

Li, J., Sun, Q., Sun, Y., Chen, B., Wu, X., And Le, T. (2019). Improvement of banana postharvest quality using a novel soybean protein isolate/cinnamaldehyde/ 
zinc oxide bionanocomposite coating strategy. Scientia Horticulturae, 258, 108786, doi: 10.1016/j. scienta.2019.108786.

Liu, L., Liu, L., Liu, C. K., Fishman, M. L., and Hicks, K. B. (2007). Composite films from pectin and fish skin gelatin or soybean flour protein. Journal of Agricultural and Food Chemistry, 55(6), 2349-2355, doi: 10.1021/jf062612u.

Liu, R., Liu, D., Liu, Y., Song, Y., Wu, T., and Zhang, M. (2017). Using soy protein $\mathrm{SiOx}$ nanocomposite film coating to extend the shelf life of apple fruit. International Journal of Food Science \& Technology, 52(9), 2018-2030, doi: 10.1111/ijfs.13478.

Madbouly, A. K., Elyousr, K. A. A., And Ismail, I. M. (2020). Biocontrol of Monilinia fructigena, causal agent of brown rot of apple fruit, by using endophytic yeasts. Biological Control, 144, 104239, doi: 10.1016/j.biocontrol.2020.104239.

Mahfoudhi, N., And Hamdi, S. (2015). Use of almond gum and gum arabic as novel edible coating to delay postharvest ripening and to maintain sweet cherry (Prunus avium) quality during storage. Journal of Food Processing and Preservation, 39(6), 14991508, doi: 10.1111/jfpp.12369.

Magbool, M., Ali, A., Alderson, P. G., Mohamed, M. T. M., SiddiQui, Y., ANd ZAhid, N. (2011). Postharvest application of gum arabic and essential oils for controlling anthracnose and quality of banana and papaya during cold storage. Postharvest Biology and Technology, 62(1), 71-76, doi: 10.1016/j. postharvbio.2011.04.002.

Marin-Felix, Y., Groenewald, J. Z., Cai, L., Chen, Q., Marincowitz, S., Barnes, I., and Crous, P. W. (2017). Genera of phytopathogenic fungi: GOPHY 1. Studies in Mycology, 86, 99-216, doi: 10.1016/j. simyco.2017.04.002.

Maringgal, B., Hashim, N., Tawakkal, I. S. M. A., and Mohamed, M. T. M. (2020). Recent advance in edible coating and its effect on fresh/fresh-cut fruits quality. Trends in Food Science \& Technology, 96, 253-267, doi: 10.1016/j.tifs.2019.12.024.

Martini, C., AND MARI, M. (2014). Monilinia fructicola, Monilinia laxa (Monilinia rot, brown rot). In S. Bautista-Baños (Ed.), Postharvest decay (pp. 233-265). Cambridge, Massachusetts, USA: Academic Press.

Mchugh, T. H. (2000). Protein-lipid interactions in edible films and coatings. Food/Nahrung, 44(3), 148-151, doi: 10.1002/1521-3803(20000501)44:3<148::AIDFOOD148>3.0.CO;2-P.

Moraes Bazioli, J., Belinato, J. R., Costa, J. H., Akiyama, D. Y., Pontes, J. G. D. M., Kupper, K. C., Augusto, F., De Carvalho, J. E., and Fill, T. P. (2019). Biological control of citrus postharvest phytopathogens. Toxins, 11(8), 460, doi: 10.3390/ toxins11080460.

Mossa, A. T. H., Mohafrash, S. M., Ziedan, E. S. H., Abdelsalam, I. S., and Sahab, A. F. (2021). Development of eco-friendly nanoemulsions of some natural oils and evaluating of its efficiency against postharvest fruit rot fungi of cucumber. Industrial Crops and Products, 159, 113049, doi: 10.1016/j. indcrop.2020.113049.

Müller, C. M., Yamashita, F., And Laurindo, J. B. (2008). Evaluation of the effects of glycerol and sorbitol concentration and water activity on the water barrier properties of cassava starch films through a solubility approach. Carbohydrate Polymers, 72(1), 82-87, doi: 10.1016/j.carbpol.2007.07.026.

Musto, M., Potenza, G., and Francesco, C. (2014). Inhibition of Penicillium digitatum by a crude extract from Solanum nigrum leaves. Biotechnology, Agronomy, Society and Environment, 18(2): 174-180.

Nabigol, A., And Asghari, A. (2013). Antifungal activity of Aloe vera gel on quality of minimally processed pomegranate arils. International Journal of Agronomy and Plant Production, 4(4), 833-838.

Navarro, D., Díaz-Mula, H. M., Guillén, F., Zapata, P. J., Castillo, S., Serrano, M., and MartínezRomero, D. (2011). Reduction of nectarine decay caused by Rhizopus stolonifer, Botrytis cinerea and Penicillium digitatum with Aloe vera gel alone or with the addition of thymol. International Journal of Food Microbiology, 151(2), 241-246, doi: 10.1016/j. ijfoodmicro.2011.09.009.

Nawab, A., Alam, F., and Hasnain, A. (2017). Mango kernel starch as a novel edible coating for enhancing shelf-life of tomato (Solanum lycopersicum) fruit. International Journal of Biological Macromolecules, 103, 581-586, doi: 10.1016/j.ijbiomac.2017.05.057.

Ncama, K., Magwaza, L. S., Mditshwa, A., And TESfAy, S. Z. (2018). Plant-based edible coatings for managing postharvest quality of fresh horticultural produce: A review. Food Packaging and Shelf Life, 16, 157-167, doi: 10.1016/j.fpsl.2018.03.011.

Nieto, M. B. (2009). Structure and function of polysaccharide gum-based edible films and coatings. In K. C. Huber, M. E. Embuscado (Eds), Edible films and coatings for food applications (pp. 57-112). New York, NY, USA: Springer. doi: 10.1007/978-0387-92824-1_3.

Nor, S. M., AND Ding, P. (2020). Trends and advances in edible biopolymer coating for tropical fruit: A review. Food Research International, 109208, doi: 10.1016/j.foodres.2020.109208.

Nowicki, M., Nowakowska, M., Niezgoda, A., And KoziK, E. (2012).Alternaria black spot of crucifers: symptoms, importance of disease, and perspectives of resistance breeding. Vegetable Crops Research Bulletin, 76(1), 5-19, doi: 10.2478/v10032-012-0001-6.

Ortega-Toro, R., Morey, I., Talens, P., and Chiralt, A. (2015). Active bilayer films of thermoplastic starch and polycaprolactone obtained by compression molding. Carbohydrate Polymers, 127, 282-290, doi: 10.1016/j.carbpol.2015.03.080. 
Palou, L. (2014). Penicillium digitatum, Penicillium italicum (green mold, blue mold). In S. BautistaBaños (Ed.), Postharvest decay (pp. 45-102). Academic Press. doi: 10.1016/B978-0-12-4115521.00002-8.

Palou, L., Smilanick, J. L., and Droby, S. (2008). Alternatives to conventional fungicides for the control of citrus postharvest green and blue moulds. Stewart Postharvest Review, 2(2), 1-16, doi: 10.2212/ spr.2008.2.2.

Papoutsis, K., Mathioudakis, M. M., Hasperué, J. H., AND Ziogas, V. (2019). Non-chemical treatments for preventing the postharvest fungal rotting of citrus caused by Penicillium digitatum (green mold) and Penicillium italicum (blue mold). Trends in Food Science \& Technology, 86, 479-491, doi: 10.1016/j. tifs.2019.02.053.

Parreidt, S. T., Müller, K., and Schmid, M. (2018). Alginate-based edible films and coatings for food packaging applications. Foods, 7(10), 170, doi: 10.3390/foods 7100170 .

Patten, A. M., Vassão, D. G., Wolcott, M. P., Davin, L. B., AND Lewis, N. G. (2010). 3.27 Trees: A remarkable biochemical bounty. Comprehensive Natural Products, II, 1173-1296.

Pérez, S., Rodríguez-Carvajal, M. A., and Doco, T. (2003). A complex plant cell wall polysaccharide: rhamnogalacturonan II. A structure in quest of a function. Biochimie, 85(1-2), 109-121, doi: 10.1016/ s0300-9084(03)00053-1.

Pérez-Alfonso, C. O., Martínez-Romero, D., Zapata, P. J., Serrano, M., Valero, D., and Castillo, S. (2012). The effects of essential oils carvacrol and thymol on growth of Penicillium digitatum and P. italicum involved in lemon decay. International Journal of Food Microbiology, 158(2), 101-106, doi: 10.1016/j. ijfoodmicro.2012.07.002.

Renkema, J. M., and Van Vliet, T. (2002). Heatinduced gel formation by soy proteins at neutral $\mathrm{pH}$. Journal of Agricultural and Food Chemistry, 50(6), 1569-1573, doi: 10.1021/jf0107631.

Rhim, J. W., PArk, H. M., And Ha, C. S. (2013). Bionanocomposites for food packaging applications. Progress in Polymer Science, 38(10-11), 1629-1652, doi: 10.1016/j.progpolymsci.2013.05.008.

Ritchie, D. F. (2000). Brown rot of stone fruits. The Plant Health Instructor, doi: 10.1094./PHI-I-2000-1025-01.

Riva, S. C., Opara, U. O., and Fawole, O. A. (2020). Recent developments on postharvest application of edible coatings on stone fruit: A review. Scientia Horticulturae, 262, 109074, doi: 10.1016/j. scienta.2019.109074.

Rizwana, H., Bokahri, N. A., Alsahli, S. A., Al Showiman, A. S., Alzahrani, R. M., and Aldehaish, H. A. (2021). Postharvest disease management of Alternaria spots on tomato fruit by Annona muricata fruit extracts. Saudi Journal of Biological Sciences, 28(4), 2236-2244, doi: 10.1016/j.sjbs.2021.01.014.
Rosca-Casian, O., Parvu, M., Vlase, L., and Tamas, M. (2007). Antifungal activity of Aloe vera leaves. Fitoterapia, 78(3), 219-222, doi: 10.1016/j. fitote.2006.11.008.

Ruffo Roberto, S., Youssef, K., Hashim, A. F., And IpPolito, A. (2019). Nanomaterials as alternative control means against postharvest diseases in fruit crops. Nanomaterials, 9(12), 1752, doi: 10.3390/ nano9121752.

Shehata, S. A., Abdeldaym, E. A., Ali, M. R., Mohamed, R. M., Bob, R. I., And Abdelgawad, K. F. (2020). Effect of some citrus essential oils on postharvest shelf life and physicochemical quality of strawberries during cold storage. Agronomy, 10(10), 1466, doi: 10.3390/agronomy10101466.

Shivas, R. G., Tan, Y. P., Edwards, J., Dinh, Q., Maxwell, A., Andic, V., And Weir, B. S. (2016). Colletotrichum species in Australia. Australasian Plant Pathology, 45(5), 447-464, doi: 10.1007/ s13313-016-0443-2.

Shukla, R., And Cheryan, M. (2001). Zein: the industrial protein from corn. Industrial Crops and Products, 13(3), 171-192, doi: 10.1016/S09266690(00)00064-9.

Silva, C., And Michereff, S. J. (2013). Biology of Colletotrichum spp. and epidemiology of the anthracnose in tropical fruit trees. Revista Caatinga, 26(4), 130-138.

SrivastaVA, L. M. (2002). Plant growth and development: Hormones and environment. Oxford: Elsevier.

Staats, M., Van Baarlen, P., Schouten, A., Van Kan, J.A.L., AND BAKKer, F.T. (2007). Positive selection in phytotoxic protein-encoding genes of Botrytis species. Fungal Genetics and Biology, 44, 52-63, doi: 10.1016/j.fgb.2006.07.003.

Subirade, M., Kelly, I., Guéguen, J., and Pézolet, M. (1998). Molecular basis of film formation from a soybean protein: comparison between the conformation of glycinin in aqueous solution and in films. International Journal of Biological Macromolecules, 23(4), 241-249, doi: 10.1016/s01418130(98)00052-x.

Thakur, R., Pristijono, P., Bowyer, M., Singh, S. P., Scarlett, C. J., Stathopoulos, C. E., and Vuong, Q. V. (2019). A starch edible surface coating delays banana fruit ripening. $L W T-$ Food Science and Technology, 100, 341-347, doi: 10.1016/j. lwt.2018.10.055.

Thakur, V. K., and Thakur, M. K. (Eds). (2016). Handbook of sustainable polymers: processing and applications. Boca Raton, Florida, USA: CRC Press.

Thomidis, T. (2014). Fruit rots of pomegranate (cv. Wonderful) in Greece. Australasian Plant Pathology, 43(5), 583-588, doi: 10.1007/s13313-0140300-0.

Thompson, A. K. (2008). Fruit and vegetables: harvesting, handling and storage. Hoboken, New Jersey, USA: John Wiley \& Sons. 
Timmer, L. W., Peever, T. L., Solel, Z. V. I., And Akimitsu, K. (2003). Alternaria diseases of citrus - Novel pathosystems. Phytopathologia Mediterranea, 42(2), 99-112, doi: 10.14601/Phytopathol_Mediterr-1710.

Troncoso-Rojas, R., And Tiznado-Hernández, M. E. (2014). Alternaria alternata (black rot, black spot). In S. Bautista-Baños (Ed.), Postharvest decay (pp. 147-187). Cambridge, Massachusetts, USA: Academic Press.

Uysal-Morca, A., And Kinay-Teksür, P. (2019). Brown rot caused by Monilinia fructicola on Japanese plums in Turkey. Journal of Plant Pathology, 102, 589, doi: 10.1007/s42161-019-00473-6.

Valdes, A., Burgos, N., Jiménez, A., And Garrigós, M. C. (2015). Natural pectin polysaccharides as edible coatings. Coatings, 5(4), 865-886, doi: 10.3390/ coatings 5040865 .

Wei, L., Chen, C., Chen, J., Lin, L., And Wan, C. (2021). Possible fungicidal effect of Citral on kiwifruit pathogens and their mechanisms of actions. Physiological and Molecular Plant Pathology, 114, 101631, doi: 10.1016/j.pmpp.2021.101631.

Williamson, B., Tudzynski, B., Tudzynski, P., And VAN KAN, J. A. (2007). Botrytis cinerea: the cause of grey mould disease. Molecular Plant Pathology, 8(5), 561-580, doi: 10.1111/j.1364-3703.2007.00417.x.

Xavier, K. V., Kc, A. N., Peres, N. A., Deng, Z., Castle, W., Lovett, W., and Vallad, G. E. (2019). Characterization of Colletotrichum species causing anthracnose of pomegranate in the Southeastern United States. Plant Disease, 103(11), 2771-2780, doi: 10.1094/PDIS-03-19-0598-RE.

Yahia, E. M., Ornelas-Paz, J. D. J., and Elansari, A. (2011). Postharvest technologies to maintain the quality of tropical and subtropical fruits. In E. M. Yahia (Ed.), Postharvest biology and technology of tropical and subtropical fruits (pp. 142-195e). Cambridge, UK: Woodhead Publishing Limited.

Yang, R., Miao, J., Shen, Y., Cai, N., Wan, C., Zou, L., Chen, C., And Chen, J. (2021). Antifungal effect of cinnamaldehyde, eugenol and carvacrol nanoemulsion against Penicillium digitatum and application in postharvest preservation of citrus fruit. LWT - Food Science and Technology, 141, 110924, doi: 10.1016/j.lwt.2021.110924.

Youssef, K., Roberto, S. R., and De Oliveira, A. G. (2019). Ultra-structural alterations in Botrytis cinerea - The causal agent of gray mold - Treated with salt solutions. Biomolecules, 9(10), 582, doi: 10.3390/biom9100582.

Youssef, K., Roberto, S. R., Tiepo, A. N., Constantino, L. V., De Resende, J. T. V., And Abo-ElyousR, K. A. M. (2020). Salt solution treatments trigger antioxidant defense response against gray mold disease in table grapes. Journal of Fungi, 6(3), 179, doi: 10.3390/jof6030179.

Received: April 8, 2021; accepted: May 29, 2021. 